\title{
Shear Strength of Concrete Members: Challenges, Recent Developments and Possibilities
}

ISSN: 2639-0574

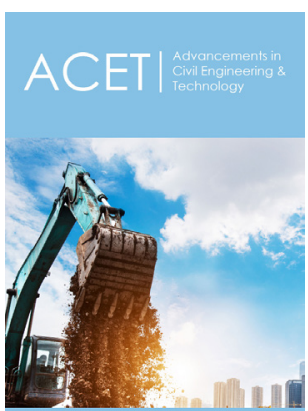

${ }^{* 1}$ Corresponding author: Victor Aguilar, Facultad de Ingeniería y Tecnología, Universidad San Sebastián, Chile, E-mail: vha0001@ auburn.edu

Submission: 眥 February 17, 2020

Published: 䟧 March 05, 2020

Volume 4 - Issue 1

How to cite this article: Aguilar V, Barnes $\mathrm{R}$, Nowak A. Shear Strength of Concrete Members: Challenges, Recent Developments and Possibilities. Adv Civil Eng Tech. 4(1). ACET.000580.2020.

DOI: 10.31031/ACET.2020.04.000580

Copyright@ Victor Aguilar, This article is distributed under the terms of the Creative Commons Attribution 4.0 International License, which permits unrestricted use and redistribution provided that the original author and source are credited.

\author{
Victor Aguilar ${ }^{1,2 *}$, Robert Barnes ${ }^{1}$ and Andrzej Nowak ${ }^{1}$ \\ ${ }^{1}$ Department of Civil Engineering, Auburn University, USA \\ ${ }^{2}$ Facultad de Ingeniería y Tecnología, Universidad San Sebastián, Chile
}

\section{Introduction}

Shear strength of concrete members has always been a complex topic, and even today, there is no widespread agreement regarding a shear resistance model. Nevertheless, the primary resistance mechanisms have been identified [1] shear transfer through uncracked concrete, aggregate interlock along cracks, dowel action of longitudinal reinforcement, arch action for short and deep members, and amount of shear reinforcement. It is assumed that the shear strength is the sum of the concrete contribution and the shear reinforcement contribution. However, the quantification of these mechanisms is not straightforward. The shear strength of concrete members is influenced by tensile concrete strength, coarse aggregate size, presence of axial force, slenderness ratio $(\mathrm{M} / \mathrm{Vd}$ or $\mathrm{a} / \mathrm{d}$, where $\mathrm{M}$ is the bending moment, $\mathrm{V}$ is the shear force, $d$ is the effective depth of the longitudinal reinforcement, and a is the shear span, i.e., distance between the applied load and the support), amount of longitudinal reinforcement, and overall size of the member. Yet, the relative influence of these variables is still debated.

\section{Challenges}

Difficult questions have emerged: Is the behavior of members with or without shear reinforcement similar enough that they can be analyzed with the same model? Is the assumption of a $45^{\circ}$ angle in the truss model for shear reinforcement contribution reasonably accurate? How and when to account for the size effect? And how to account for beam action or arch action behavior? Researchers have pointed out that the failure modes are significantly different in shear-reinforced members than members without transverse reinforcement; therefore, the concrete contribution to the shear strength should also be different [2]. Some researchers have suggested the use of an angle flatter than $45^{\circ}$ for the shear reinforcement contribution $[3,4]$. Tests have shown that the average shear stress at failure decreases as the size of the cross section increases [5] (size effect). Researches have not agreed upon the source of this size effect nor how to account for it. It remains controversial whether it should be considered for members with and without shear reinforcement, or only for members without shear reinforcement. The beam slenderness is closely related to the member behavior, and it plays a role in determining the failure mode of shear-critical elements. Thus, it is not rare to find a slenderness ratio as an input parameter in shear strength equations. Nevertheless, if slenderness is expressed as $\mathrm{M} / \mathrm{Vd}$, which is the critical cross-section to consider? Some shear strength models use the geometric slenderness ratio, a/d, which is only directly applicable to the maximum moment and shear force for simply supported beams loaded with concentrated loads. Then, which are the appropriate moment and shear values for continuous beams and uniformly loaded members?

In the U.S., reinforced concrete members for buildings are designed in accordance with ACI 318 Building code requirements for structural concrete. The traditional one-way shear methods in ACI 318-14 [6] have long been widely used, despite criticisms [5,7,8] they are heavily empirical instead of based on a physical mechanism; the concrete contribution is the same in members without considering the presence of shear reinforcement; the slenderness is only considered in combination with the amount of longitudinal reinforcement, which renders the bending moment effect redundant; the influence of axial compression due to external loads and due to prestressing is accounted differently, which prevents a unified design framework; 
the influence of axial tension may be overly conservative; the provisions do not extend to high-strength concrete; they do not account for size effect; and they are unconservative when applied to the design of large beams with little longitudinal reinforcement.

\section{Recent Developments}

Over time, several shear resistances models have been proposed: e.g., the tooth model [9], modified compression field theory [10], multi-action model [4], fracture mechanics [11], and models based on the depth of the compression zone [12-15]. A great research effort has been made over the past several decades to understand the shear performance of concrete structures to achieve safer and more efficient designs. The research has been supported by the collaboration between the ACI Subcommittee 318-E Section and Member Strength, the joint ACI-ASCE Committee 445 Shear and Torsion, the joint ACI-ASCE Committees 446 Fracture Mechanics of Concrete, the German Committee for Reinforced Concrete (DAfStb), and the International Federation for Structural Concrete (fib). As a result, databases have been gathered and new one-way shear equations have been developed. Six oneway shear proposals intended to unify the design of reinforced and prestressed concrete while addressing the identified drawbacks in the ACI 318 traditional shear design specifications were recently published [8]. Furthermore, ACI 318-19 [16] updated the one-way shear model with a new set of empirical equations [7].

\section{Possibilities}

A simple yet accurate approach is required for the design of new structural components. However, some applications require a higher level of accuracy, e.g., forensic engineering and evaluation of existing structures. Hence, there is room for the inclusion of the new alternative one-way shear equations in engineering practice. Studies on the accuracy and reliability-based calibrations of these alternatives are recommended, so they can transition from research findings to application by practitioners. In addition to the research about one-way shear in slender concrete members, the strut-andtie modeling approach has gained acceptance and interest among structural engineers. This approach was heavily developed in the late 1980s [17] and was introduced to the U.S. practice in the AASHTO LRFD Bridge design specifications [18] in 1994. ACI 31802 [19] included the strut-and-tie method as an appendix, and ACI 318-14 [6] moved the method to the main body of the document. The specifications for strut-and-tie design method were extended and updated in ACI 318-19 [16]. As the research continues, updates in provisions for two-way shear, torsion, and shear design of deep members are expected.

\section{References}

1. Kuchma DA, Collins MP (1998) Advances in understanding shear performance of concrete structures. Progress in Structural Engineering and Materials 1(4): 360-369.

2. Reineck KH (2017) Proposal for ACI 318 shear design. Concrete International 39(9): 65-70.

3. Bentz EC, Collins MP (2017) Updating the ACI shear design provisions. Concrete International 39(9): 33-38.

4. Cladera A, Marí A, Bairán JM, Oller E, Ribas C (2017) One-way shear design method based on a multi-action model. Concrete International 39(9): 40-46.

5. Collins MP, Kuchma D (1999) How safe are our large, lightly reinforced concrete beams, slabs, and footings? Structural Journal 96(4): 482-490.

6. ACI 318-14 (2014) Building code requirements for structural concrete and commentary. American Concrete Institute, Farmington Hills, Michigan, USA.

7. Kuchma DA, Wei S, Sanders DH, Belarbi A, Novak LC (2019) Development of the one-way shear design provisions of ACI 318-19 for reinforced concrete. ACI Structural Journal 116(4): 285-295.

8. Belarbi A, Kuchma DA, Sanders DH (2017) Proposals for new one-way shear equations for the 318-building code. Concrete International 39(9): 29-32.

9. Kani GNJ (1964) The riddle of shear failure and its solution. Journal Proceedings 61(4): 441-468.

10. Vecchio F, Collins MP (1986) The modified compression-field theory for reinforced concrete elements subjected to shear. ACI J 83(2): 219-231.

11. Bažant ZP, Oh BH (1983) Crack band theory for fracture of concrete. Matériaux et construction 16(3): 155-177.

12. Wolf TS, Frosch RJ (2007) Shear design of prestressed concrete: A unified approach. Journal of structural Engineering 133(11): 1512-1519.

13. Park HG, Choi KK (2017) Unified shear design method of concrete beams based on compression zone failure mechanism. Concrete International 39(9): 59-63.

14. Tureyen AK, Frosch RJ (2003) Concrete shear strength: Another perspective. Structural Journal 100(5): 609-615.

15. Frosch RJ, Yu Q, Cusatis G, Bažant ZP (2017) A unified approach to shear design. Concrete International 39(9): 47-52.

16. ACI 318-19 (2019) Building code requirements for structural concrete and commentary. American Concrete Institute, Farmington Hills, Michigan, USA.

17. Schlaich J, Schafer K, Jennewein M (1987) Towards a consistent design of reinforced concrete structures. PCI Journal 32(3): 74-150.

18. AASHTO (1994) AASHTO LRFD bridge design specifications. ( $\left.1^{\text {st }} \mathrm{edn}\right)$, American Association of State Highway and Transportation Officials, Washington, USA.

19. ACI 318-02 (2002) Building code requirements for structural concrete and commentary. American Concrete Institute, Farmington Hills, Michigan, USA. 